\title{
Sodium Chloride Resistance in Selected Cultivars of Hedera helix
}

\author{
David B. Headley ${ }^{1}$, Nina Bassuk ${ }^{2}$, and Robert G. Mower ${ }^{3}$ \\ Department of Floriculture and Ornamental Horticulture, Room 20 Plant \\ Science Building, Cornell University, Ithaca, NY 14853 \\ Additional index words. English ivy, salt
}

\begin{abstract}
Two experiments were conducted to determine the relative resistance of 33 selected cultivars of English ivy (Hedera helix L.) to soil- and shoot-applied NaCl. In the soil-applied $\mathrm{NaCl}$ experiment, ramets of the 33 cultivars were irrigated with a fertilizer + 0.25-N NaCl solution for 55 days. 'Harrison', 'Hibernica', 'Thorndale', Wilson', and Woerner' exhibited the least amount of visible shoot damage. Dry weights of all cultivars were much lower in the salt treatment. In the shoot-applied $\mathrm{NaCl}$ experiment, plants were sprayed daily with a $0.25-\mathrm{N} \mathrm{NaCl}$ solution for 48 days. The young leaves and stems of all cultivars were severely injured by the salt spray, while the mature leaves and stems and the dormant buds were only slightly injured. Reduction in dry weight varied between cultivars. Two subsequent experiments focused on resistance to soil-applied NaCl. Ramets of the NaCl-resistant 'Harrison', 'Hibernica', and 'Thorndale', and the NaCl-sensitive 'Baltica', 'Cathedral Wall', and Wingertsberg' were irrigated with a fertilizer $+0.25-\mathrm{N} \mathrm{NaCl}$ solution for 48 days. Whole-plant $\mathrm{Cl}$ content for all six cultivars was in the range of $30,000 \mathrm{ppm}$. Ramets of 'Thorndale' and 'Cathedral Wall' were irrigated with a fertilizer $+0.25-\mathrm{N} \mathrm{NaCl}$ solution for 30 days with replicate plants harvested at $\mathbf{S}$-day intervals. 'Cathedral Wall' accumulated more $\mathrm{Cl}$ at a faster rate than 'Thorndale'. Mean whole-plant $\mathrm{Cl}$ concentration peaked at $97,000 \mathrm{ppm}$ for 'Cathedral Wall' and $40,000 \mathrm{ppm}$ for 'Thorndale'. Salt resistance may be partly based on slower uptake of $\mathrm{Cl}$.
\end{abstract}

English ivy is an evergreen vine native to Europe and western Asia, having more than 400 known variants (SM. Sulgrove, personal communication). Hedera helix is one of the most valuable plants for ground and wall cover. It can grow in sun and shade and in a wide range of soils. Variants of this species may be grown in U.S. Dept. of Agriculture (USDA) zones 4-9 (Flint, 1983). Hedera helix presently is being used to plant traffic medians and roadside areas. In northem areas of the United States, $\mathrm{NaCl}$ in the form of rocksalt is extensively used to melt ice on roadways in winter. Salt may come in contact with a roadside plant in two ways: 1) salt-contaminated runoff may drain into nearby plantings, thus inundating the root

Received for publication 22 Aug. 1991. Accepted for publication 17 Oct. 1991. We thank Pat Hammer and Ed Broadbent of Longwood Gardens, Kennett Square, Pa., and Sabina Sulgrove of the American Ivy Society, Dayton, Ohio, for generously supplying the plant material required for this study. The cost of publishing this paper was defrayed in part by the payment of page charges. Under postal regulations, this paper therefore must be hereby marked advertisement solely to indicate this fact.

'Graduate Assistant

Associate Professor and Director of the Urban Horticulture Institute.

${ }^{3}$ Professor. system; or 2) traffic-generated salt spray may drift from the roadway onto the leaves and stems. There is abundant evidence that rocksalt is injurious to roadside vegetation (Hanes et al., 1970; Sucoff, 1975; Westing, 1969). One of the easiest ways to prevent salt damage is to use plants known to be salt-resistant.

Dirr (1975) studied the effects of soil- and shoot-applied salts on one variant of $H$. helix. He reported that $H$. helix is fairly resistant to soil-applied $\mathrm{NaCl}$, but is severely damaged by shoot-applied $\mathrm{NaCl}$. He determined that the damage was due specifically to $\mathrm{Cl}$ - ion toxicity and not to $\mathrm{Na}+$ ion toxicity or the osmotic effect of the salt, Brawley and Mathes (1990) compared five cultivars of $H$. helix, but found only a small range of salt resistance among these cultivars.

The purpose of this study was to determine whether there is a range of $\mathrm{NaCl}$ resistance in this species and to help elucidate the mechanism of resistance if it existed. First, 33 selected cultivars of $H$. helix were screened for resistance to soil- and shoot-applied $\mathrm{NaCl}$. Because these cultivars varied greatly in resistance to soil-applied $\mathrm{NaCl}$ but varied little in resistance to shoot-applied $\mathrm{NaCl}$, the remainder of this study focused on the mechanism of soil-applied $\mathrm{NaCl}$ resistance. The amount and the rate by which $\mathrm{Cl}$ is accumulated was compared for a small set of salt- 


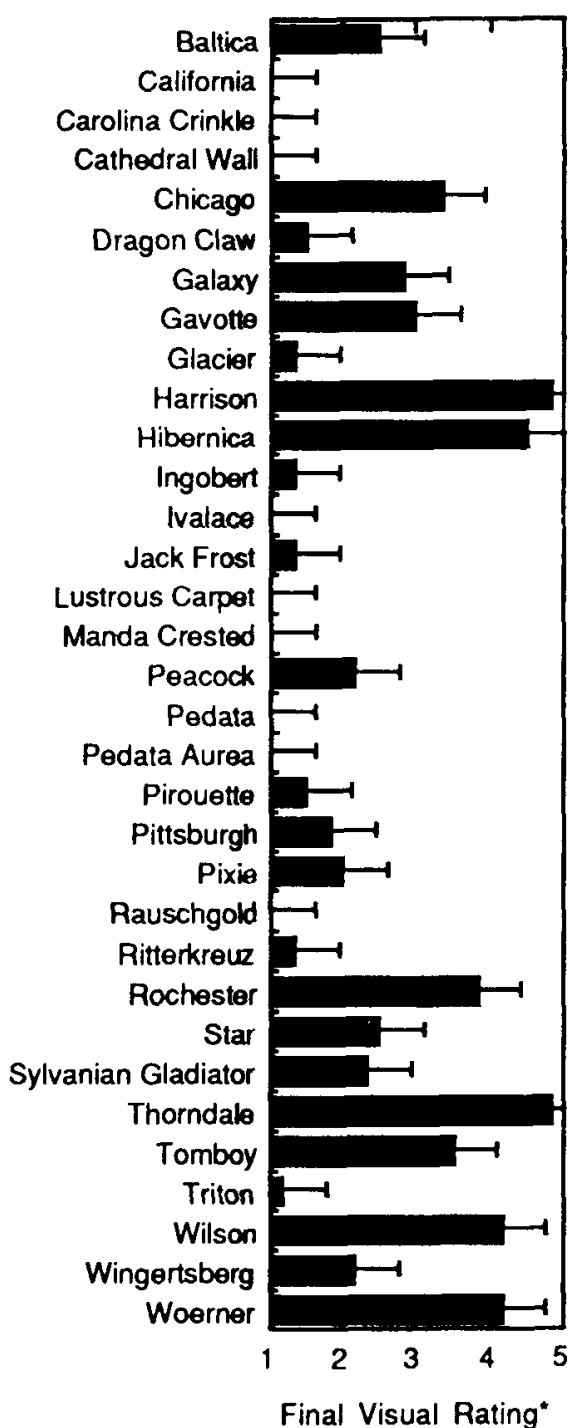

Fig. 1. Comparison of shoot condition of 33 cultivars of Hedera helix in response to soil-applied salt $(0.25 \mathrm{~N} \mathrm{NaCl})$. "Final visual rating: $1=$ shoot $96 \%$ to $100 \%$ necrotic; $5=$ shoot $0 \%$ to $5 \%$ necrotic. Each error bar represents LSD 0.05 of 0.62 visual rating units.

resistant and salt-sensitive cultivars. A plant that takes up large amounts of $\mathrm{Cl}$ can become saturated to the point of toxicity and death. Furthermore, a plant that accumulates $\mathrm{Cl}$ too quickly may not have time to adapt, osmotically or otherwise, before toxic levels are reached. Studying the mechanism of salt resistance in $H$. helix may lead to a better understanding of salt stress and may determine ways to manage this problem in this and other species.

Plant material. Thirty-three cultivars of $H$. helix selected for this study represent the wide morphological diversity within the species. The American Ivy Society plant identification number is provided for each clone. The cultivars were: 'Baltica' (83-63), 'California' (88-264), 'Carolina Crinkle' (88-267), 'Cathedral Wall' (79-149), 'Chicago' (88269), 'Dragon Claw' (88-198), 'Galaxy' (81120), 'Gavotte' (88-206), 'Glacier' (88-208), 'Harrison' (79-330), 'Hibernica' (85-55, syn. H. hibernica Kirch.), 'Ingobert' (81-72),

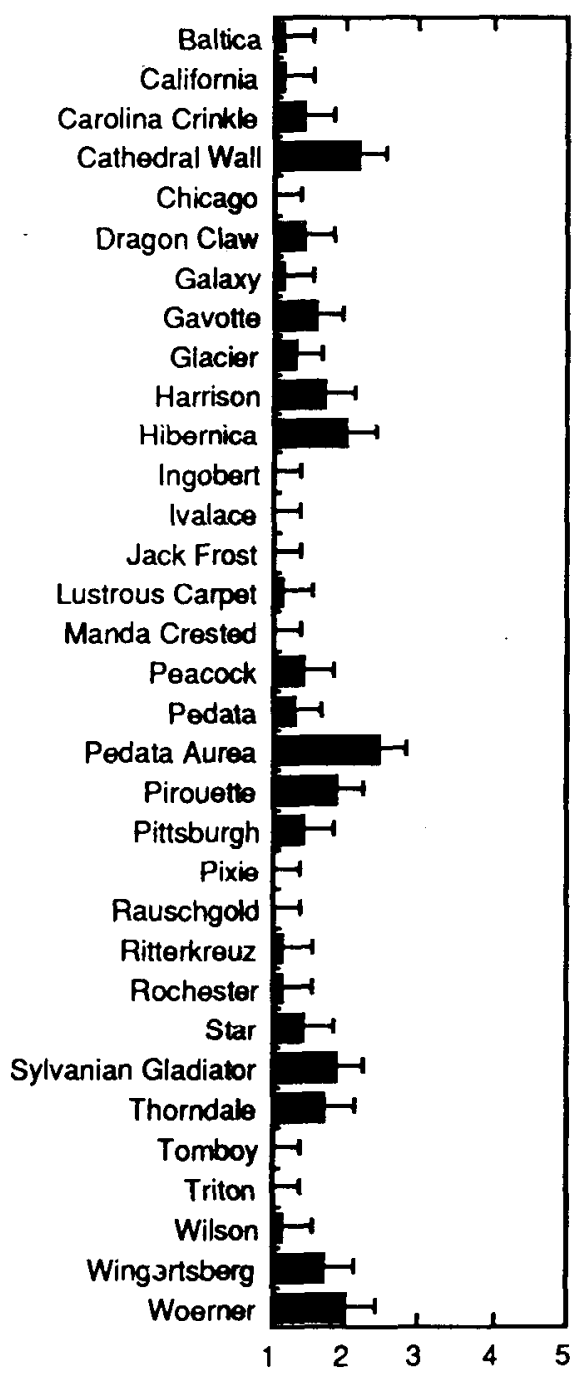

Final Visual Rating*

Fig. 2. Comparison of young shoot condition of 33 cultivars of Hedera helix in response to shootapplied salt $(0.25 \mathrm{~N} \mathrm{NaCl})$. *Final visual rating: $1=$ stems and leaves $100 \%$ necrotic; $5=$ stems healthy, leaves $0 \%$ to $5 \%$ necrotic. Each error bat represents LSD 0.05 of 0.39 visual rating units.

'Ivalace' (88-215), 'Jack Frost' (79-292), 'Lustrous Carpet' (79-268), 'Manda Crested (88-221), 'Peacock' (88-230), 'Pedata' (88231), 'Pedata Aurea' (79-4), 'Pirouette' (83183), 'Pittsburgh' (79-221), 'Pixie' (88-233), 'Rauschgold' (81-195), 'Ritterkreuz' (81199), 'Rochester' (88-236), 'Star' (88-243), 'Sylvanian Gladiator' (79-170), 'Thorndale' (88-247), 'Tomboy' (88-249), 'Triton' (7924), 'Wilson' (80-70), 'Wingertsberg' (81194), and 'Woerner' (79-428). These cultivars are known or are thought to be coldhardy to at least USDA zone 7 (Sulgrove, 1988). Ramets of the 33 cultivars of shoot length 20 to $60 \mathrm{~cm}$ were grown in 0.4-liter plastic pots in a 1 peat : 1 perlite $(\mathrm{v} / \mathrm{v})$ mixture amended with $1.14 \mathrm{~kg}$ triple superphosphate $/ \mathrm{m}^{3}, 3.5 \mathrm{~kg}$ calcium nitrate $/ \mathrm{m}^{3}$, and 0.60 $\mathrm{kg}$ dolomitic limestone $/ \mathrm{m}^{3}$. Plants were irrigated with a solution of Peter's Peat-Lite Special fertilizer $(20.0 \mathrm{~N}-4.2 \mathrm{P}-16.6 \mathrm{~K})$ with trace elements at a rate of $300 \mathrm{ppm} \mathrm{N}$. The plants were grown in a greenhouse at $20 \mathrm{C}$ day/16C night under $18 \mathrm{~h}$ daylength maintained by supplemental HID illumination at a height of $1.75 \mathrm{~m}$.

Soil-applied salt (Expt. 1). Potted plants were placed onto a lath-covered greenhouse bench, and the shoots were supported by wire. Every 2 to 3 days, all pots were leached with two 150-ml overhead applications of tapwater followed by a 300-ml application of fertilizer solution of the formulation noted (control) or a 300-ml application of fertilizer solution plus $\mathrm{NaCl}$. To reduce osmotic shock, the $\mathrm{NaCl}$ concentration of the salt treatment was gradually increased to $0.25 \mathrm{~N}$ in three steps over the first week of the experiment. Electrical conductivities (EC) of the irrigation solutions of the control and salt treatment were 0.1 and $3.1 \mathrm{~S} \cdot \mathrm{m}^{-1}$, respectively. All solutions were delivered to the pots via a drip irrigation system. The experiment was designed as a factorial arrangement of 33 cultivars and two treatments with six replicates in a complete randomized block (CRB) design. The soil applied experiment was terminated after 55 days.

Condition of the shoot of each plant was evaluated visually. Based on the damage, a pretransformed five-step scale was developed to assign a final visual rating (FVR) to each plant, where: 1 = shoot dead or nearly so, $96 \%$ to $100 \%$ necrotic; $2=$ shoot severely damaged, $66 \%$ to $95 \%$ necrotic; $3=$ shoot moderately damaged, $36 \%$ to $65 \%$ necrotic; $4=$ shoot lightly damaged, $6 \%$ to $35 \%$ necrotic; $5=$ shoot healthy or nearly so, $0 \%$ to $5 \%$ necrotic. Plants were harvested, washed, then dried at 60C for 3 days and weighed. Relative growth (RG) for all cultivars was determined where $\mathrm{RG}=$ dry weight (DW) of plant in salt treatment/DW of plant in the control.

Shoot-applied salt (Expt. 2). The bottom and sides of a greenhouse bench were lined with a sheet of polyethylene. A second sheet of polyethylene was stretched over the top of the bench and slits were made in it. A potted plant was slipped through each slit so that only the shoot protruded above. The slits then were sealed with plastic adhesive tape. The upper plastic sheet prevented any salt from coming in contact with the soil mix in the pots. Plants were bottom-irrigated by periodically flooding the bench to a depth of 2 $\mathrm{cm}$ with fertilizer solution of the same formulation as above. Plants were sprayed daily with either distilled, deionized water (control), or $0.25 \mathrm{~N} \mathrm{NaCl}$ using a pressurized hand sprayer at a pressure of 280 to $420 \mathrm{kPa}$ until liquid was dripping off the foliage. The experiment was designed as a factorial arrangement of 33 cultivars and two salt treatments with seven replicates in a randomized split-block (RSB) design. Plants were grown under the same temperature and light regimes as mentioned above. The experiment was terminated after 48 days because little change in plant condition occurred during the final 3 weeks.

Condition of the shoots then was visually evaluated. There was a differential response to the salt spray between the older (the prox- 


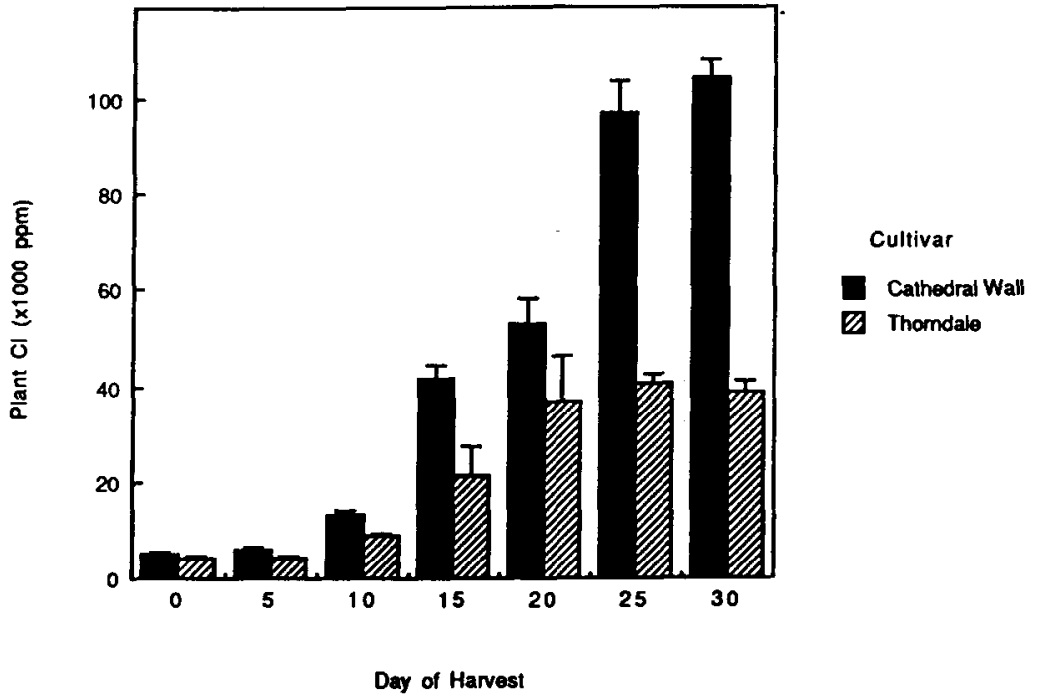

Fig. 3. Comparison of rate of chloride accumulation by Hedera helix cultivars Cathedral Wall and Thorndale in response to soil-applied salt $(0.25 \mathrm{~N} \mathrm{NaCl})$. Bars represent SE.

imal $1 / 2$ to $2 / 3$ ) and the younger (the distal $1 / 2$ to $1 / 3$ ) portions of the shoot. Therefore, the portions were evaluated separately. Based on the nature of the damage, a pretransformed five-step scale was used to assign a FVR where: $1=$ stems and leaves $100 \%$ necrotic; 2 = stems healthy and leaves $91 \%$ to $100 \%$ necrotic; $3=$ stems healthy and leaves $41 \%$ to $90 \%$ necrotic; $4=$ stems healthy and leaves $6 \%$ to $40 \%$ necrotic; $5=$ stems healthy and leaves $0 \%$ to $5 \%$ necrotic. Plants were harvested, washed, then dried at $60 \mathrm{C}$ for 3 days and weighed. Relative growth was determined as described above.

Comparison of six cultivars of varying soil salt resistance for whole-plant accumulation of $\mathrm{Cl}$ (Expt. 3). Ramets of the $\mathrm{NaCl}$-resistant 'Harrison', 'Hibernica', and 'Thorndale', and the NaCl-sensitive 'Baltica', 'Cathedral Wall', and 'Wingertsberg' of 40 to $60 \mathrm{~cm}$ initial shoot length were irrigated for 48 days with either fertilizer solution or fertilizer +0.25 $\mathrm{N} \mathrm{NaCl}$ solution. The experiment was designed as a factorial arrangement of six cultivars and two salt concentrations with 10 replicates in a complete randomized (CR) design. The irrigation solution formulation, irrigation schedule, irrigation method, temperature, and daylength regimes were the same as above.

Plants were evaluated with the five-step scale used for the soil-applied salt experiment. Plants were then harvested, washed, and rinsed with two 10-sec rinses in tap water and one 10-sec rinse in deionized distilled water. Plants then were dried at $65 \mathrm{C}$ for 3 days. Dried plant samples were ground in a mill equipped with a 40-mesh screen. A 0.15 $\mathrm{g}$ dry sample was mixed into $40 \mathrm{ml}$ of 0.125 $\mathrm{N} \mathrm{HNO}_{3}$ for $15 \mathrm{~min}$ and allowed to settle for $1 \mathrm{~h}$. Ten milliliters of $0.5 \mathrm{~N} \mathrm{KOH}$ was added to raise the $\mathrm{pH}$ of the mixture to 1.5 . A 10 $\mathrm{ml}$ aliquot of extract was mixed with $10 \mathrm{ml}$ $1.0 \mathrm{~N} \mathrm{KNO}_{3}$ and used for $\mathrm{Cl}$ analysis. Direct potentiometric measurement of $\mathrm{Cl}$ was performed using an ion meter (model 130; Corning Glass Works, Medfield, Mass.) equipped with a combination $\mathrm{Cl}$ electrode (model 9617BN; Orion Research, Boston) and a set of standards.

Comparison of two cultivars for rate of accumulation of $\mathrm{Cl}$ (Expt. 4). Ramets of 'Cathedral Wall' and 'Thorndale' were irrigated every 2 to 3 days for 30 days with a fertilizer $+0.25 \mathrm{~N} \mathrm{NaCl}$ solution. A set of plants of each cultivar was harvested at 5day intervals and analyzed for $\mathrm{Cl}$ content as described above. The experiment was designed as a factorial arrangement with two cultivars and seven harvest dates with six replicates in a $\mathrm{CR}$ design. The $\mathrm{NaCl}$-amended irrigation solution formulation, irrigation schedule, irrigation method, temperature regimes, and daylength were as described above.

Statistical analysis. Analysis of variance (ANOVA) was performed on the experimental data. For Expts. 1 and 2, Fisher's least significant difference (LSD) test was used to compare cultivars. For Expts. 3 and 4, Tukey's studentized range (HSD) test, as well as linear contrasts, were used to compare cultivars within each treatment. Comparisons of means were conducted at $P=0.05$. Statistical analysis was performed using the general linear models procedure of SAS, version 5.16 (SAS Institute, Cary, N.C.).

'Harrison', 'Thorndale', 'Hibernica', 'Wilson', and 'Woerner' exhibited the least phytotoxicity to soil-applied $\mathrm{NaCl}$ (Fig. 1). 'California', 'Carolina Crinkle', 'Cathedral Wall', 'Ivalace', 'Lustrous Carpet', 'Manda Crested', 'Pedata', 'Pedata Aurea', and 'Rauschgold' exhibited the most. Dirr (1975) reported that a variant of $H$. helix was resistant to the osmotic effect and $\mathrm{Na}^{+}$of soilapplied $\mathrm{NaCl}$ but was sensitive to $\mathrm{Cl}$-. Therefore, the five cultivars that sustained the least visible damage are not only resistant to the osmotic effect and $\mathrm{Na}^{+}$toxicity, but also to $\mathrm{Cl}$ - ion toxicity. Dry weight of plants of all 33 cultivars in the soil-applied $\mathrm{NaCl}$ treatment was $15 \%$ to $30 \%$ of the control (detailed data not shown). Cultivars that performed marginally better than the rest include 'Peacock', 'Pixie', and 'Carolina
Crinkle'. When evaluating the performance of ornamentals in response to stress, however, appearance of the plant may take priority over rate of growth (Bernstein et al., 1972). Therefore, when screening for superior salt resistance, as in the case of $H$. helix, cultivar selection should be based primarily on appearance and secondarily on growth rate.

The old growth of most cultivars suffered little or no visible damage from shoot-applied $\mathrm{NaCl}$ (data not shown). In contrast, the actively growing apices and the young stems and leaves of all cultivars were severely damaged by salt spray (Fig. 2). Following the death of the shoot meristems, the dormant axillary buds commenced active growth, but the resulting young shoots also were killed by the salt spray. Growth of most cultivars was adversely affected (35\% to $60 \%$ of control on a dry-weight basis) by the daily application of salt spray, although effects were generally not as severe as in the soil-applied salt experiment, presumably due to the shorter duration of treatment. Growth was least affected by shoot-applied $\mathrm{NaCl}$ in 'Peacock', 'Pirouette', -'Jack Frost', and 'Sylvanian Gladiator', and most affected in 'Rochester', 'Glacier', and 'Cathedral Wall'.

Simini (1984) proposed that NaCl-contaminated water is unlikely to penetrate a leaf via the stomates, but rather through the leaf's epicuticular wax and cuticle. More epicuticular wax is deposited on a leaf's surface over time (Skoss, 1955) and leaf cuticle thickens with age (Leopold and Kriedemann, 1975). As a result, older leaves (and stems) repel polar liquids, like water, better than younger ones. Thus, older shoot material is more resistant to foliar-applied $\mathrm{NaCl}$ than is younger material probably because of its ability to exclude salt from sensitive sites within the shoot.

Salt may be a problem in two landscape situations. Salt spray in coastal areas may affect growth year around, damaging and killing new growth as it arises; $H$. helix in such a situation would perform poorly. In areas adjacent to roadways and sidewalks that receive de-icing salts in winter, plants of $H$. helix may be exposed to both soil- and shootapplied salt generally only during the dormant season. In this situation, there may be significant interaction between salt exposure and cold hardiness in this species, because $\mathrm{NaCl}$ can reduce cold hardiness in plants (Levitt, 1980; Sucoff and Hong, 1976). However, evidence indicates this only happens when $\mathrm{NaCl}$ is present inside the tissues of the plant. For soil-applied $\mathrm{NaCl}$, cultivars demonstrating resistance to soil-applied $\mathrm{NaCl}$ at room temperature may not show good resistance during winter, if plants accumulate $\mathrm{NaCl}$ in winter. However, because salt uptake by roots is greatly reduced during the winter (Walton, 1969), the problem of reduced hardiness may not be significant. For shoot-applied $\mathrm{NaCl}$, minor damage would be expected because only small amounts of $\mathrm{NaCl}$ would penetrate the shoot since most, if not all, of the shoot is mature growth with thick cuticles and waxes on its surfaces. Only more research will determine if this is the case. 
Clearly, time of salt application and the prevailing temperature need to be taken into consideration when evaluating $\mathrm{NaCl}$ resistance. In areas that receive large amounts of salt-contaminated run-off from a nearby road, a cold-hardy $H$. helix cultivar that has been shown to be resistant to soil-applied $\mathrm{NaCl}$ might be grown successfully.

In Expt. 3, plants of 'Hibernica', 'Thorndale', and 'Baltica' displayed the least amount of damage (FVR of 3.6, 3.8, and 3.4, respectively) from soil-applied $\mathrm{NaCl}$. 'Cathedral Wall' and 'Wingertsberg' sustained major shoot damage (FVR of 1 and 1.9, respectively). There was a significant difference in shoot damage between 'Cathedral Wall' and the three resistant cultivars. However, all plants to which salt was applied accumulated large amounts of $\mathrm{Cl}(30,000 \pm 2200 \mathrm{ppm}$ on a dry-weight basis).

Plants of 'Cathedral Wall' accumulated roughly the same amount of $\mathrm{Cl}$ in 24 days (all plants of this cultivar were dead by day 24) as the resistant cultivars in 48 days. Assuming an end to $\mathrm{Cl}$ accumulation at death, plants of 'Cathedral Wall' accumulate $\mathrm{Cl}$ about twice as fast as the resistant cultivars. 'Cathedral Wall' may accumulate $\mathrm{Cl}$ so fast that it may not have time to adapt to high levels of $\mathrm{Cl}$.

All plants of Cl-sensitive 'Cathedral Wall' were dead by day 15 , while only $20 \%$ of the plants of the more salt-resistant 'Thorndale' were dead at the conclusion of the experiment on day 30. During the experiment, 'Thorndale' had accumulated much less $\mathrm{Cl}$ than 'Cathedral Wall' (Fig. 3). 'Cathedral Wall' not only took up $\mathrm{Cl}$ faster than 'Thorndale', but also accumulated $\mathrm{Cl}$ to extremely high levels (up to $116,000 \mathrm{ppm}$ or $11.6 \%$ in some plants). This amount is much higher than the 30,000 to $40,000 \mathrm{ppm}$ level reported by Dirr (1975). In addition, this level of $\mathrm{Cl}$ for 'Cathedral Wall' was much higher than that found in Expt. 3. This difference might have been due to leaching of $\mathrm{Cl}$ from the necrotic plant tissues continued overhead irrigation with tap water to remove excess salts from the media in Expt. 3. Leaching of $\mathrm{Cl}$ occurs faster from necrotic regions of needles in Pinus strobus than from living tissue, resulting in lower $\mathrm{Cl}$ content for necrotic tissue (Hofstra and Hall, 1971; Hall et al., 1972).

The results of Expts. 3 and 4 suggest that $\mathrm{Cl}$ resistance of 'Thorndale' may be based on a Cl- ion exclusion mechanism and/or an ability to sequester $\mathrm{Cl}$ away from sensitive sites. However, no evidence of either mehanism at the supercellular level was found using X-ray microanalysis (Headley, 1990). Therefore, the data suggest 'Thorndale' has one or more of the following: 1) a slower $\mathrm{Cl}$ - ion uptake/transport mechanism; 2) its physiological processes tolerate higher levels of $\mathrm{Cl} ; 3$ ) it can safely localize $\mathrm{Cl}$ in subcellular parts (such as in the vacuole of the cell).

Results from this study indicate that $H$. helix exhibits differences in sensitivity to salt between young and mature shoots and may be used in locations where plants are exposed to salt spray only during the dormant season. With careful cultivar selection, Hedera helix may be used successfully in landscape situations where salt is a problem.

\section{Literature Cited}

Bernstein, L., L.E. Francois, and R.A. Clark. 1972 Salt tolerance of ornamental shrubs and groundcovers. J. Amer. Soc. Hort. Sci. 97:550-556.

Brawley, J. and M.C. Mathes. 1990. The influence-of $\mathrm{NaCl}$ on the growth of English ivy (Hedera helix) cuttings and callus tissue. Environ. Expt. Bot. 30:43-50.

Dirr, M. 1975. Effects of salts and application methods on English ivy. HortScience 10:182184

Flint, H. 1983. Landscape plants for eastern North America. Wiley, New York.

Hall, R., G. Hofstra, and G.P. Lumis. 1972. Effects of deicing salt on eastern white pine: Foliar injury, growth suppression and seasonal changes in foliar concentrations of sodium and chloride. Can. J. For. Res. 2:244-249.

Hanes, R.E., L.W. Zelazny, and R.W. Blaser. 1970. Effects of deicing salts on water quality and biota. Literature review and recommended research. Natl. Coop. Highway Res. Prog. Rpt. 91.

Headley, D.B. 1990. Sodium chloride resistance in English ivy, Hedera helix, and effect of time of dormant season application of sodium chlo- ride on injury in trees. PhD Diss., Cornell Univ., Ithaca, N.Y.

Hofstra, G. and R. Hall. 1971. Injury on roadside trees: Leaf injury on pine and white cedar in relation to foliar levels of sodium and chloride. Can. J. Bot. 49:613-622.

Leopold, A.C. and P.E. Kriedemann. 1975. Plant growth and development. 2nd ed. McGraw-Hill. New York.

Levitt, J. 1980. Response of plants to environmental stresses. vol. II. Water, radiation, salt, and other stresses. 2nd ed. Academic, New York.

Simini, M. 1984. De-icing salt in New Jersey: Its effects on growth; and the role of epicuticular wax as a tolerance mechanism in trees. $\mathrm{PhD}$ Diss., Rutgers Univ., New Brunswick, N.J.

Skoss, J. 1955. Structure and composition of plant cuticle in relation to environmental factors and permeability. Bot. Gaz. 117:55-72.

Sucoff, E. 1975. Effect of deicing salts on woody vegetation along Minnesota roads. Minnesota Agr. Expt. Sta. Tech. Bul. 303.

Sucoff, E. and S.G. Hong. 1976. Effect of $\mathrm{NaCl}$ on cold hardiness of Malus spp. and Syringa vulgaris. Can. J. Bot. 54:2816-2819.

Walton, G.S. 1969. Phytotoxicity of $\mathrm{NaCl}$ and $\mathrm{CaCl}_{2}$ to Norway maples. Phytopathology 59:1412-1415.

Westing, A.H. 1969. Plants and salt in the roadside environment. Phytopathology 59:11741181 . 